\title{
LOCAL TERRITORIAL AGENTS AND LETHAL VIOLENT CRIMES, MACAPÁ-BRAZIL
}

\author{
ALMEIDA, Leidiene Souza de; ${ }^{\text {* }}$ CHAGAS, Clay Anderson Nunes; ${ }^{\mathrm{b}}$ \\ RAMOS, , Edson Marcos Leal Soares ${ }^{c}$
}

\begin{abstract}
(a) MSc. in Public Security. Captain of the Military Police State of Amapá (PMAP). ORCID ID: http://orcid.org/0000-0001-7480-9089. CURRICULUM LATTES: http://lattes.cnpq.br/5411520453003641

(b) Phd. in Social and Environmental Planning. Professor Federal University of Pará (UFPA) and the State University of Pará (UEPA). ORCID ID: http://orcid.org/0000-0002-4223-0192. CURRICULUM LATTES: http://lattes.cnpq.br/3537327292901649
\end{abstract}

(c) Phd. in Production Engineering. Professor Federal University of Pará (UFPA). ORCID ID: http://orcid.org/0000-0001-5425-8531. CURRICULUM LATTES: http://lattes.cnpq.br/8324947891255931

\section{(*) CORRESPONDING AUTHOR}

Address: UFPA, Rua Augusto Corrêa, 1, CEP: 66075110, Belém (PA), Brasil. Tel: (+55 91) 32017996

E-mail: claychagas@yahoo.com.br

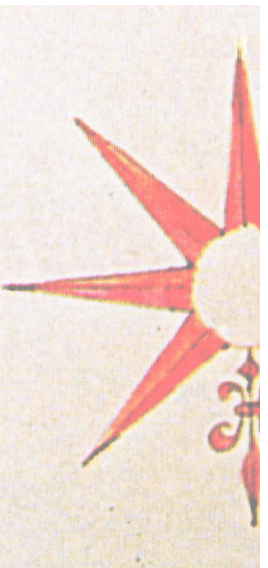

\begin{abstract}
The objective of this study is to analyze the dynamics of lethal violent crimes in the territory of the neighborhoods of Cidade Nova, Congós, Jardim Felicidade, Marabaixo I, Muca and Novo Buritizal from the perspectives of different social actors interviewed in the city of Macapá. The research was descriptive and exploratory, developed from a bibliographical survey, field research and the systematization of secondary data collected from the Statistics and Criminal Analysis Department, subordinated to the State Secretariat of Justice and Public Security of Amapá. To this end, descriptive statistical techniques were used, associated with GIS and content analysis of interviews. The results show that the violence registered in Macapá, especially on the neighborhood level, is distributed differently in the urban space, and above all, has caused fear and insecurity in the population. The perpetrators and victims of lethal crime are predominantly male adolescents and youths, as a result of conflicts arising from non-payment of debts related to the drug trade.
\end{abstract}

Keywords: Urban space; Violence; Violent crimes; Territorial agents.

\section{RESUMO / RESUMEN}

\section{AGENTES TERRITORIAIS LOCAIS E CRIMES VIOLENTOS LETAIS, MACAPÁ-BRAZIL}

O objetivo deste estudo é analisar a dinâmica dos crimes violentos letais no âmbito do território dos bairros Cidade Nova, Congós, Jardim Felicidade, Marabaixo I, Muca e Novo Buritizal, a partir da perspectiva de diferentes atores sociais entrevistados na cidade de Macapá. A pesquisa teve caráter descritivo e exploratório, sendo desenvolvida a partir de levantamento bibliográfico, pesquisa de campo e sistematização de dados secundários coletados junto à Gerência de Estatística e Análise Criminal, subordinada à Secretaria de Estado da Justiça e Segurança Pública do Amapá. Para isso, foram utilizadas técnicas da estatística descritiva, associada ao geoprocessamento e análise de conteúdo das entrevistas. Os resultados obtidos evidenciam que a violência registrada em Macapá, em especial na dimensão dos bairros, se distribui de forma diferenciada no espaço urbano, e tem provocado, sobretudo, medo e insegurança na população. Os autores e vítimas da criminalidade letal são predominantemente os adolescentes e jovens, do sexo masculino, em virtude de conflitos advindos do não pagamento de dívidas relativas ao comércio de drogas.

Palavras-chave: Espaço urbano; Violência; Crimes violentos; Agentes territoriais.

\section{ACTORES LOCALES Y LOS CRÍMENES VIOLENTOS LETALES EN MACAPÁ-BRASIL}

El objetivo de este estudio es analizar la dinámica de los crímenes violentos letales en el territorio de los distritos de Cidade Nova, Congós, Jardim Felicidade, Marabaixo I, Muca y Novo Buritizal, desde la perspectiva de diferentes actores entrevistados la ciudad de Macapá. La investigación fue descriptivo y exploratorio, que se desarrolló a partir de revisión de la literatura, la investigación de campo y sistematización de datos secundarios recogidos por la Dirección de Estadística y Análisis Criminal, dependiente del Ministerio de Justicia y Seguridad Pública de Amapá. Para esto, se utilizaron técnicas de estadística descriptiva asociados con el GIS y el contenido de análisis de entrevistas. Los resultados muestran que la violencia registrada en Macapá, especialmente en el tamaño de los cuartos, se distribuye de manera diferente en el espacio urbano, y ha causado sobre todo el miedo y la inseguridad en la población. Los autores y las víctimas del crimen letales son en su mayoría adolescentes y jóvenes, hombres, debido a los conflictos que surgen de la falta de pago de las deudas relacionadas con el tráfico de drogas.

Palabras clave: Espacio urbano; Violencia; Crímenes violentos; Agentes territoriales. 


\section{INTRODUCTION}

This article presents the results obtained in field research with local territorial agents, referring to Project BRA / 04/029 - Citizen Security / Thinking of Public Security, financed by the United Nations Development Program (UNDP) in partnership with the National Secretariat of Public Security of the Ministry of Justice (SENASP / MJ) and executed by members of the "Territory, Network and Violence" research team - territorial agents and homicides in the cities of Belém, Ananindeua, Marabá, Parauapebas, Macapá and Palmas, linked to the Postgraduate courses in Public Security and Geography of the Federal University of Pará (UFPA), which had the task of collecting and systematizing data on the phenomenon of violence and homicides, in order to identify the main risk factors and the dynamics of these crimes in the cities of the Northern Region that are part of the National Pact for Homicide Reduction (PNRH) (BRAZIL, 2016a).

The objective is to understand the relationship between the dynamics of lethal ${ }^{1}$ violent crimes and the behavior of the local territorial agents, from a field survey, in which interviews were held with different local actors active in the neighborhoods of Cidade Nova, Congós, Jardim Felicidade, Marabaixo I, Muca and Novo Buritizal, located in the city of Macapá.

To explore the theme, this study is structured in five parts: after this introduction, the second part deals with the characterization of the study area. The third discusses the methodology used in the research. The fourth deals with the results of the spatial distribution of lethal violent crimes in Macapá's districts, associated to the analysis of the interviews of the different local territorial agents. Finally, the conclusions are presented.

\section{CHARACTERIZATION OF THE STUDY AREA}

Macapá, capital of Amapá, is located in the extreme north of the country and is bordered by the state of Pará. According to data released in the 2010 Demographic Census, the total population comprises 398,204 inhabitants, the population estimate for the year 2016 is around 465,495 inhabitants (IBGE, 2010a, 2016).

In the specific context of Macapá, political and economic changes in the state over the last three decades have significantly altered the spatial configuration of the city, especially due to the transformation of the Amapá Territory into a Federative Unit through the 1988 Federal Constitution and the creation of the Free Trade Area of Macapá and Santana in 1991. These were the two main events that contributed both to the population increase in Amapá and the expansion of the capital's urban network caused by the large contingent of migrants who arrived in the municipality (PORTILHO, 2010). In addition, during the 1990s, the creation of extensive areas of environmental preservation (about $72 \%$ of the state's territory) was another determinant for the concentration of economic productive forces around the capital of the state of Amapá (PORTO et al., 2008).

Like many of the country's cities, Macapá faces a series of conflicts arising from a process of rapid and disorderly urban expansion. The municipality currently has a total of 84 neighborhoods, of which 28 were created officially; most are subnormal clusters. ${ }^{2}$ The other 56 settlements (neighborhoods) exist informally, without the respective legal instrument to establish their boundaries or the number of streets, blocks and dwellings.

The southern part of the capital of Amapá is the oldest occupied area, with an estimated population of 210,000 inhabitants (IBGE, 2010a) and has most of the municipality's tourist attractions,

(1) Intentional Lethal Violence (ILV) is a category created in 2006 by the National Secretariat of Public Security, with the purpose of aggregating crimes of greater social relevance (BRASIL, 2006). In this study, homicide, robbery-homicide and death in police confrontations.

(2) The 2010 Census Sector Boundary Handbook classifies as subnormal clusters each set consisting of 51 or more housing units characterized by the absence of title deeds and at least one of the following characteristics: irregularity of the roads and the size and shape of the lots; and / or lack of essential public services (such as garbage collection, sewage system, water network, electricity and public lighting) (IBGE, 2010a). 
economic activities, cultural activities and public services. It accommodates a large part of the population living in ressacas (floodplains), ${ }^{3}$ mainly in the neighborhoods of Congós, Marco Zero, Muca, Novo Buritizal and Universidade. The capital's ressaca areas cover a total of 36,470,392 square meters, about $20 \%$ of the total area of the city's urban perimeter, home to an estimated $17 \%$ of the urban population, which corresponds to about 65 thousand people (PEREIRA et al., 2015).

The northern zone of Macapá concentrates most of the more recent neighborhoods and subdivisions. It starts officially after the Sérgio Arruda bridge, the main link to this part of the city, with an estimated population of 130,000 inhabitants (IBGE, 2010a) and is considered the main vector of horizontal urban expansion in the capital. The central road axis is the Tancredo Neves Road and the BR 210 highway, which is the main access the other cities in the interior of the state (PALHETA et al., 2016).

It is important to highlight that the six districts that had the highest lethality in the city of Macapá in the time frame from 2013 to 2015 were selected as the object of investigation of the territorial dynamics of lethal violent crimes, as highlighted in Figure 1.

On analyzing the dynamics of lethal violent crime in the neighborhoods surveyed in Macapá, from the database provided by the Office of Statistics and Criminal Analysis (GEAC), linked to the State Secretariat of Justice and Public Security of Amapá (SEJUSP / AP), the cut totaled 130 records extracted from the of Military Police Occurrence Bulletins (MPOB), from 2013 to 2015.

It can be seen in Figure 2 that the Congós neighborhood leads the number of victims of lethal violent crime in the time series analyzed. In 2014, the neighborhoods of Jardim Felicidade, Marabaixo I and Novo Buritizal stand out, with 11, 9 and 8 victims respectively. Regarding the years 2013 and 2015, it is evident that the number of victims in the Novo Buritizal neighborhood more than doubles and triples in Marabaixo I. In the Muca neighborhood there is an increase in the number of victims, from 5 in 2013 to 7 in 2014, followed by a subtle decrease in 2015 .

\section{METHODOLOGY}

In this study, a thematic bibliographic review was carried out, followed by the collection of secondary data with GEAC-SEJUSP / AP. Subsequent descriptive and exploratory field research obtained primary data through individual interviews conducted in the first semester of 2016 in the city of Macapá, by members of the "Territory, Network and Violence" Research Team, with 34 residents from the selected neighborhoods. These dialogues were recorded (subject to prior authorization) and then transcribed for analysis.

The data analysis techniques used were descriptive statistics (BUSSAB; MORETTIN, 2013), geoprocessing for cartographic representation, using the Geographic Information System (GIS), with adaptations of the IBGE 2010 census tracts' cartographic base with ArcMap 10.1 software, with the ability to gather and link graphical objects to database structures (Càmara et al., 2004, FITZ, 2008). A thematic map with the delimitation of the territorial network of the neighborhoods was generated in order to test the hypotheses of the pattern of distribution of the criminal events investigated.

The qualitative approach was carried out through content analysis, based on the words "violence" and "homicide", to compose the analytical categories. The treatment was organized into three phases: 1) pre-analysis, through skimming the text of the interviews; 2) exploring the material, with subsequent classification and aggregation of the data into categories; and, 3) treatment of the results

(3) The word ressaca is used regionally to describe the various lagoons of floodplains in Amapá, which arise during the Amazon winter (December to June) and come from the accumulation of rainwater in rivers and streams. When the rains cease, the waters are restricted to the main river channel and the ressacas turn into large fields. They also serve as natural wind corridors, which ease thermal discomfort and directly influence the microclimate of the city, especially in the North Zone of Macapá (TAKIYAMA et al., 2003). 


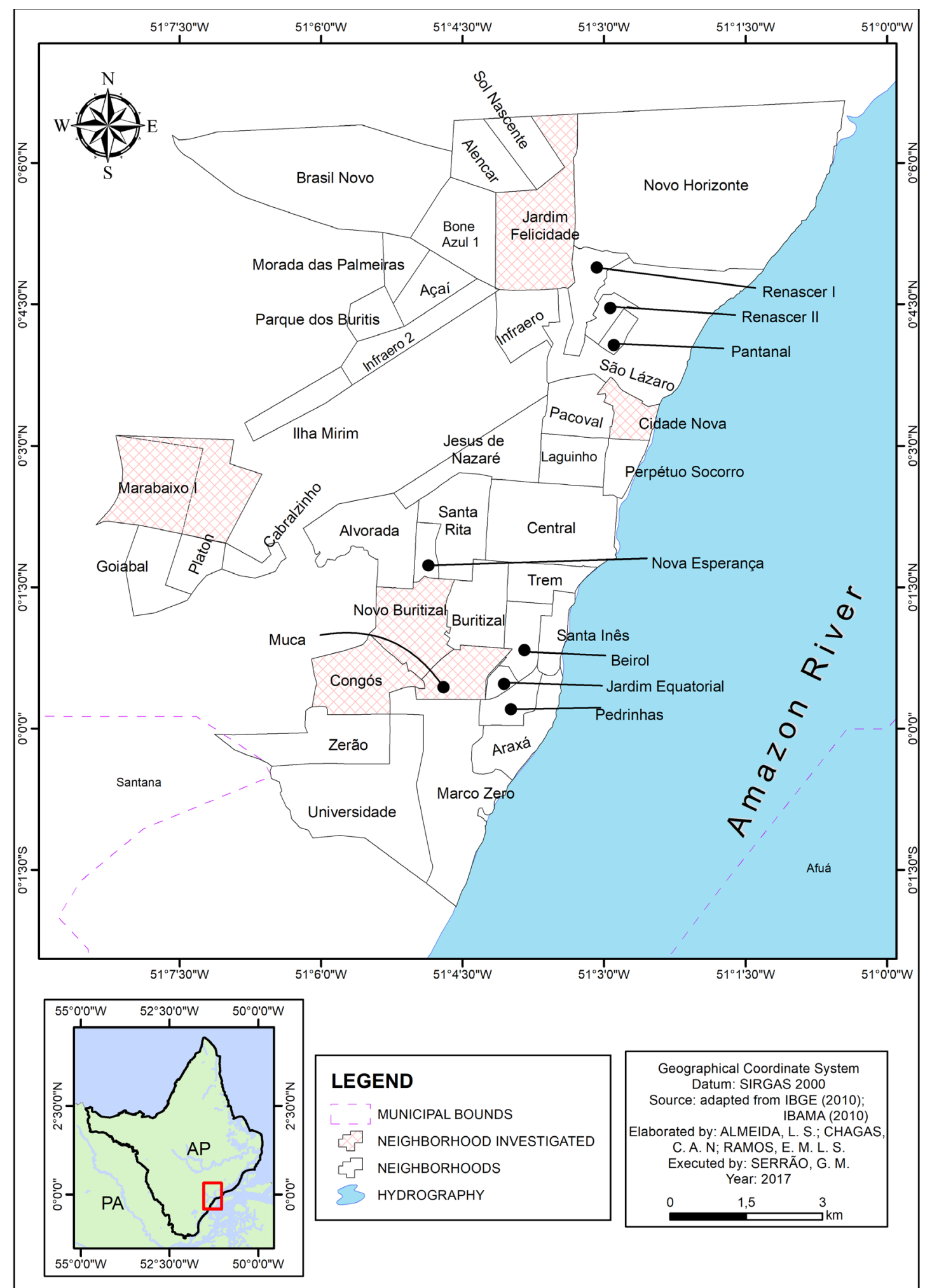

Figure 1 - Delimitation of the neighborhoods investigated in Macapá-AP.

Source: IBGE (2010) - Adapted by the authors (2017). 


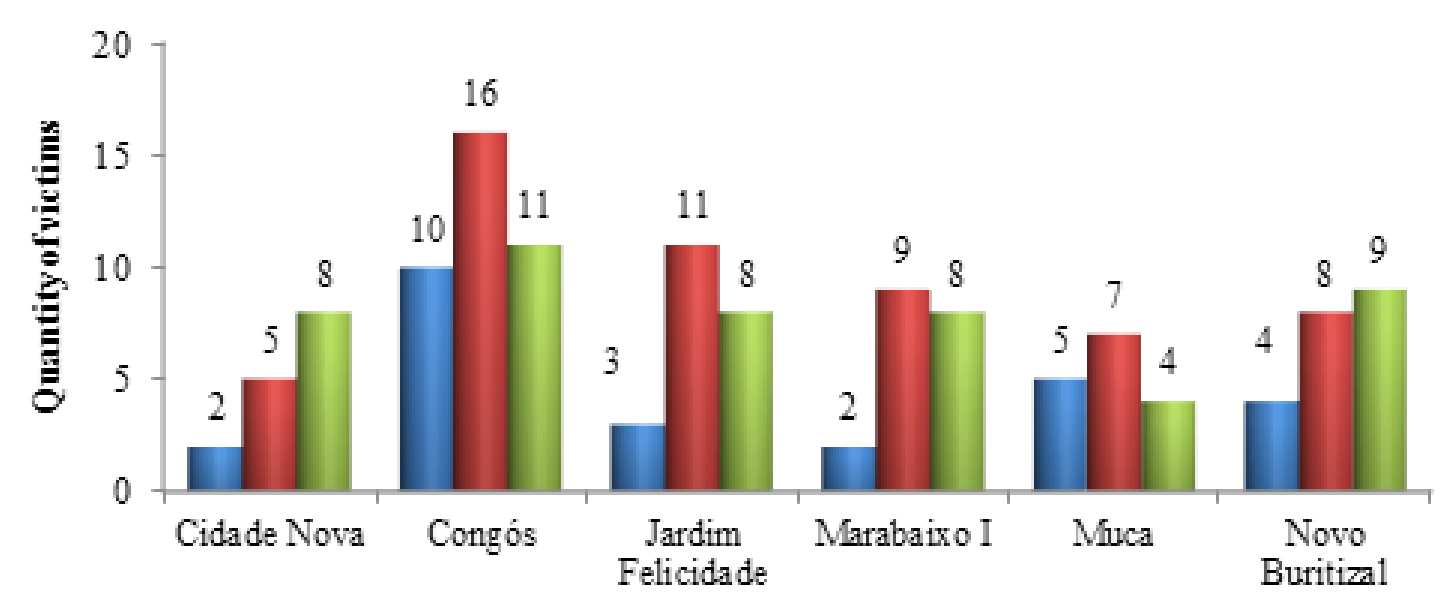

Neighborhood

Figure 2 - Number of victims of lethal violent crime in the neighborhoods surveyed in the city of Macapá-AP (2013-2015).

Source: GEAC-SEJUSP / AP (2016) - Prepared by the authors (2017).

and interpretation of the data, based on the theoretical reference framework and the indications brought by the general reading (BARDIN, 2011).

\section{RESULTS AND DISCUSSION}

\section{SPATIAL ANALYSIS}

There was a certain difficulty in the research when crossing the database at the neighborhood level with the distribution of the records of the crimes, specifically regarding a consensus of the official sources consulted about which exact area or polygon covers certain neighborhoods in the city of Macapá. Added to this, the lack of standardized and complete records of lethal violent crimes, ${ }^{4}$ made it impossible to establish the exact location of all criminal events surveyed, leading to the creation of maps showing "hot spots".

In this way, the aim was to observe the pattern, whether there was clustering or if the distribution of events was random or if their distribution was regular (BAILEY; GATRELL, 1995). In addition, perspectives on the space were sought that were not limited to its condition as a geographical space, focusing on the dimension of the territory inseparable from the social, which in this case, focused on the space-territory-power relationship, to think territorially about lethal violent crimes in the capital of Amapá.

From the spatial analysis in the neighborhoods of Jardim Felicidade (Figure 3) and Cidade Nova (Figure 4), it was possible to verify that the phenomenon is not distributed in a concentrated way, suggesting a trend with a well-defined and uniform pattern, indicating that the crimes are distributed regularly in the territory of these two districts.

Jardim Felicidade is one of the oldest neighborhoods in the north of the city, with a population of 16,672 inhabitants and 3,898 permanent private households, distributed over a total area of $2.6 \mathrm{~km}^{2}$

(4) Of the 130 records of lethal violent crime in the territory of the neighborhoods investigated, 110 events (approximately $85 \%$ of the total) were accurately spatialized. 


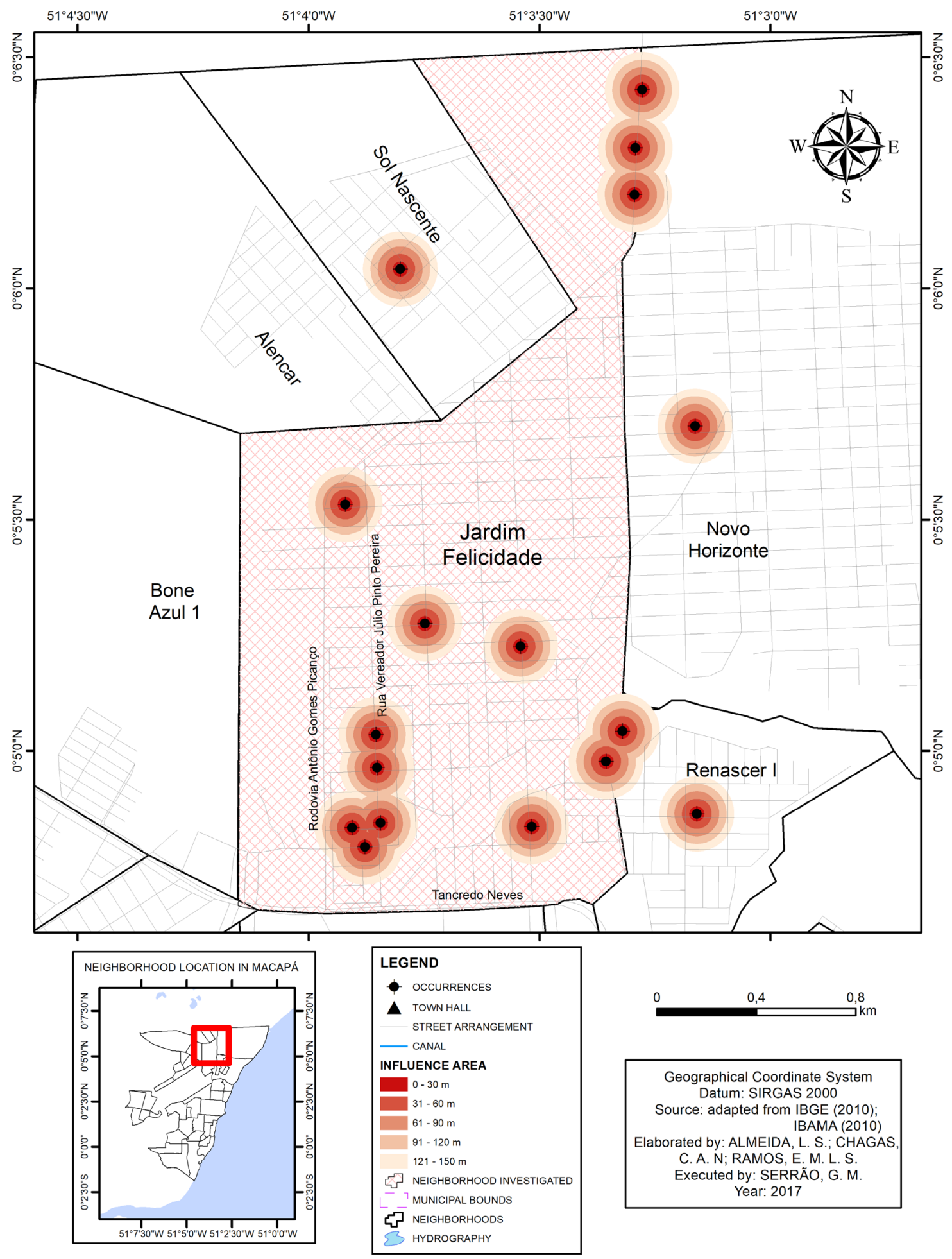

Figure 3 - Distribution of lethal violent crimes in the Jardim Felicidade neighborhood, Macapá-AP (2013-2015). 


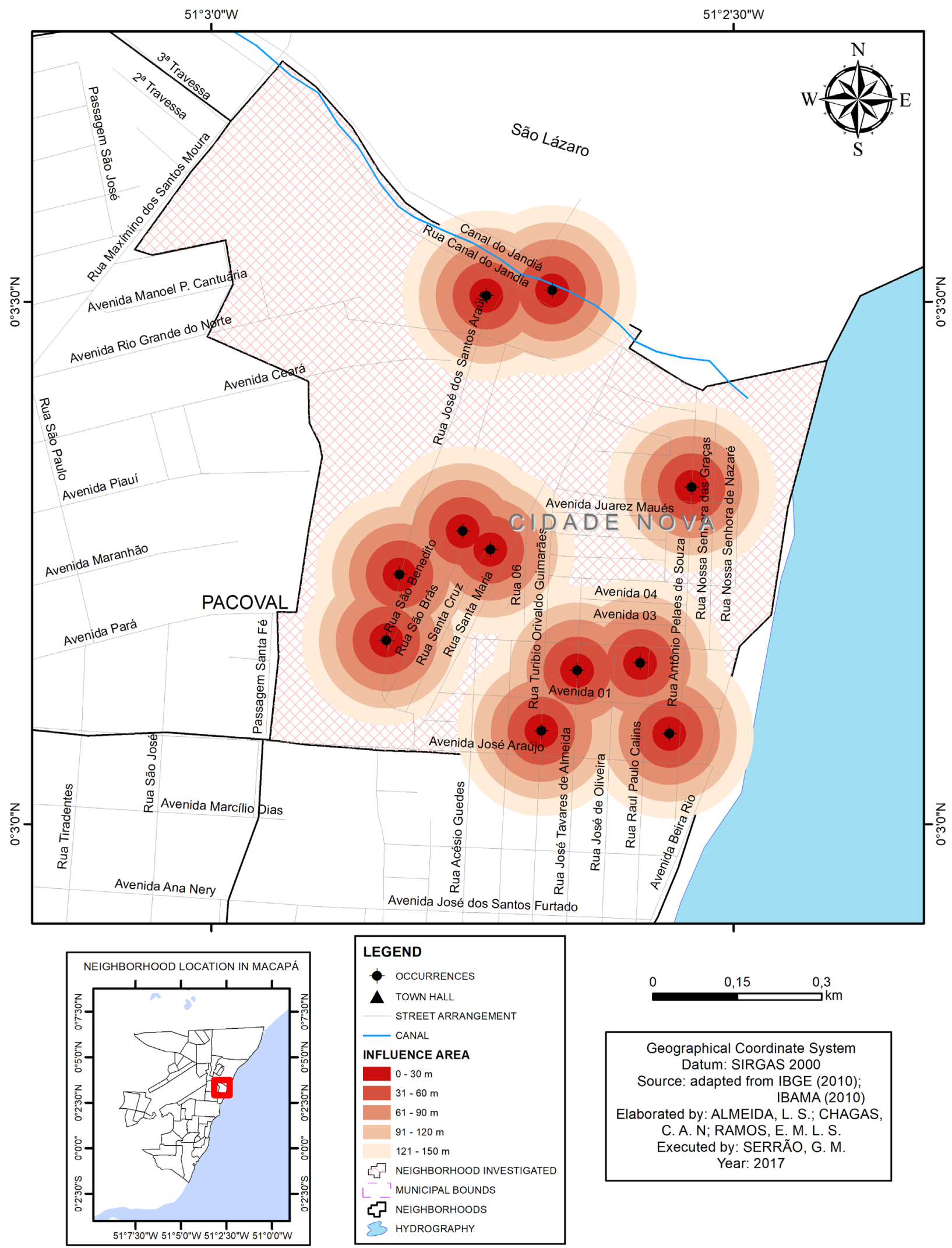

Figure 4 - Distribution of lethal violent crimes in the Cidade Nova neighborhood, Macapá-AP (2013-2015). 
(IBGE, 2010b). It is important to point out that the expansion caused by urban pressure in Macapá occurred in all directions, but especially in the northern part of the city, increasing the problems faced by the population of this region of the city, which is behind in terms of infrastructure and urban equipment, such as the lack of basic sanitation, problems with the water and electricity supply, unpaved roads, and deficiencies in transportation and public services. This administrative unit has a significant amount of housing in ressaca areas, not as densely populated as the neighborhoods of the southern area of the capital, but which has similarly been suffering from the progressive increase of the "landfill campaign" for ressaca areas, a peculiar phenomenon important in the dimension of informal housing in the capital of Amapá (TOSTES, 2006; TOSTES; LUZ, 2014). These spaces are fragmented expansions of the urban territory, neglected by the public authorities, with characteristics that exclude citizenship, which favored the weakening of the ties of social control mechanisms and the installation of violence and crime in these spaces (GOMES, 2005; BEATO FILHO, 2012).

The Cidade Nova neighborhood has a population that exceeds 15 thousand inhabitants, with 3,211 permanent private households, distributed in a total area of $0.8 \mathrm{~km}^{2}$ (IBGE, 2010b). It is located in the eastern part of the capital, in the area of the city bordering the Amazon River, where there are numerous irregular dwellings in flooded areas, with irregular connections to the electricity grid, without water and sewage infrastructure, without road paving and regular garbage collection and whose characteristics coincide with those of the exclusion area. Although the neighborhood is located in the most central part of the capital, its reality contrasts sharply with the properly subdivided, urbanized area, which has most of the main urban services in Macapá. In addition, although the Cidade Nova neighborhood is a geographically small space, it has a high flow of people, due to its commercial importance and proximity to the city center. Cidade Nova, along with the neighborhoods of Jesus de Nazaré, Pacoval and São Lázaro is located in the extension of the Jandiá Channel, where a small port area serves as an outlet for wood products (CARDOSO et al., 2015).

The Cidade Nova neighborhood has a large number of plots of abandoned land and a considerable area of irregular occupations, with a high demographic density. There is a significant loss in the quality of life, essentially as regards to the loss to the right to the city, both at the level of dwelling that is not limited to the dwelling place, and at the urban level of the city, reflected in the framework of urban disorganization found. It is noteworthy that both levels interpenetrate, adding the dynamic physical and social structure, which generates innumerable forms of production and reproduction of segregation (LEFEBVRE, 2000, 2006). It is in this environment that "territorial exclusion makes individuals, families and communities particularly vulnerable, making room for violence and conflict" (ROLNIK, 1999, p. 100).

The Marabaixo I neighborhood has been extra-officially created since 1998, and there are no official estimates of the population in the data source consulted. The neighborhood is served by the electric power system, however, it does not have a supply of treated water or basic sanitation. The streets and avenues have no identification and there is no projected urban infrastructure; it lacks asphalt, curbs, drainage and rainwater channels and signage.

As regards the distribution of lethal violent crimes in Marabaixo I (Figure 5), a certain regularity can be observed in the dispersion of events, especially along the Duca Serra Highway, the main link between the western area and the city center. There is a greater concentration of records in the space where the Institute of Penitentiary Administration of Amapá (IAPEN) is located, ${ }^{5}$ which may indicate an increase in the number of deaths in the capital's prison system. To this effect, the Criminal Justice Network Report highlights the states of the North and Northeast with the highest rates of prison mortality, especially the state of Maranhão with 75 cases for every 10,000 persons deprived of their liberty (BRAZIL, 2016b).

(5) It is important to point out that of the 19 registries of lethal violent crimes occurred in the neighborhood Marabaixo I, 8 homicides occurred within the IAPEN. 


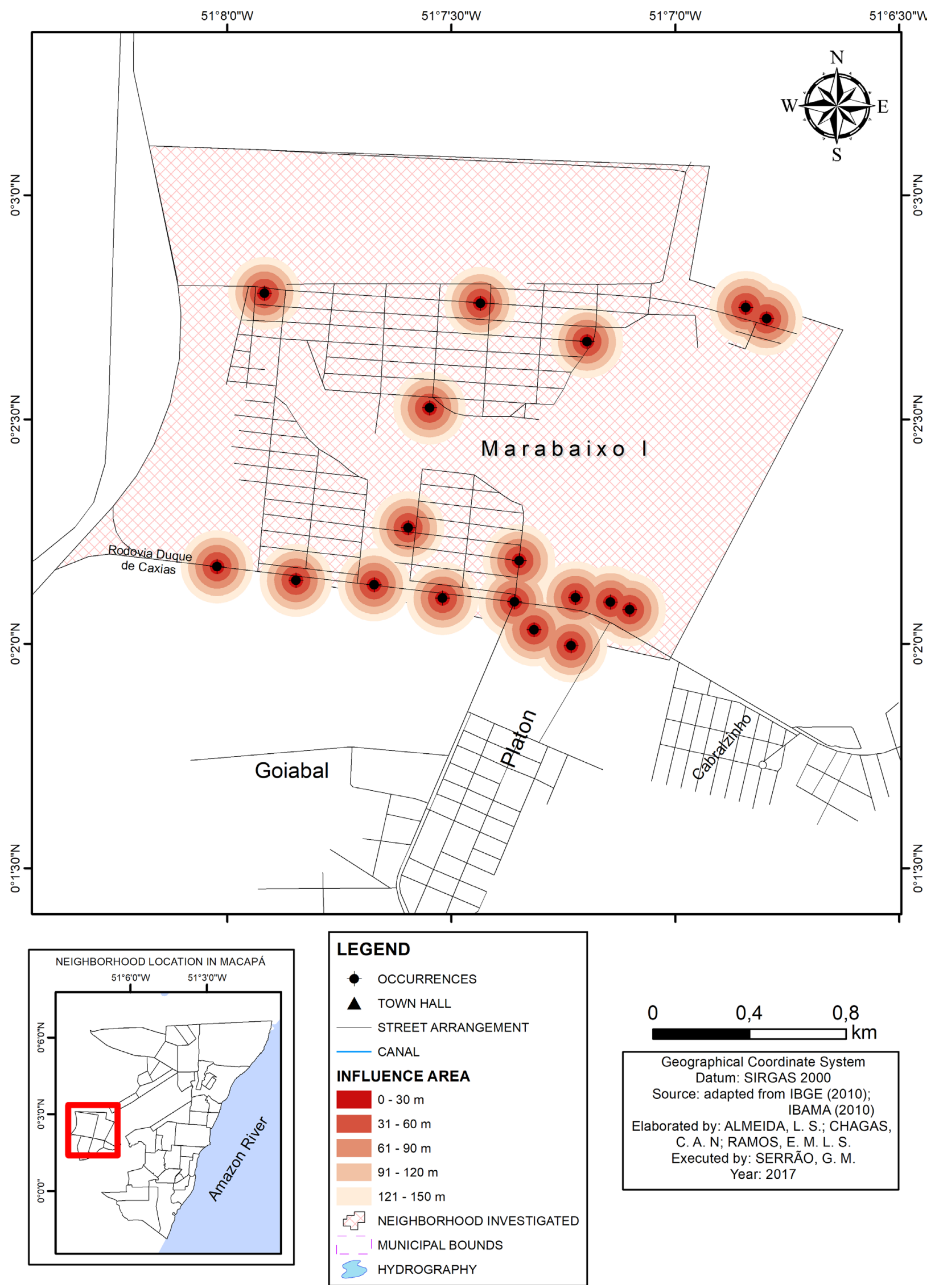

Figure 5 - Distribution of lethal violent crimes in the Marabaixo I neighborhood, Macapá-AP (2013-2015). 


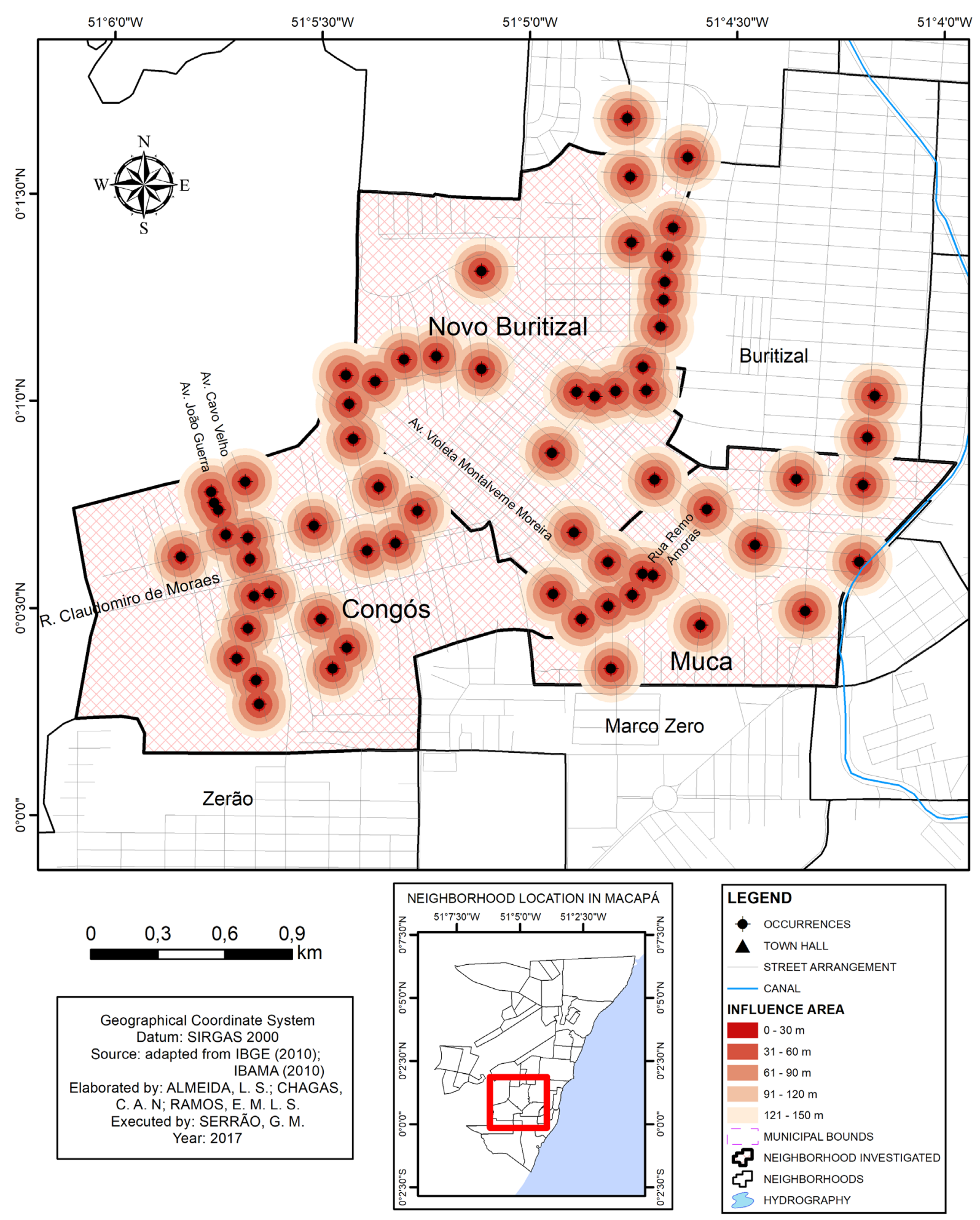

Figure 6 - Distribution of lethal violent crimes in the Congós, Muca and Novo Buritizal districts, Macapá-AP (2013-2015). 
In terms of the intra-urban concentration of crimes, the Congós, Muca and Novo Buritizal neighborhoods (Figure 6) are noteworthy, with a predominance of incidents in their border areas, which coincide with subnormal clusters in the urban space, where collective infrastructural and social living conditions are usually more precarious, especially the flood-prone parts of the administrative units, which form a conglomerate within them.

It is worth noting that the Congós, Muca and Novo Buritizal districts coexist with the serious problem of irregular occupation in the ressaca areas, which are densely populated spaces connected by wooden walkways. There is no sewage network or treated water and irregular connections to the electric power supply lines are common (PEREIRA et al., 2015).

Portilho (2010) warns that the effect of the absence of public policies aimed at land occupation and use in Macapá is the invasion of the ressacas, due to the lack of dry building land at low prices near the city center. The urban occupation in the capital advances progressively towards the peripheral and terminal zones of the neighborhoods, which usually correspond to the ressaca areas, which lacking basic urban infrastructure have become areas of segregation and poverty, resulting in a series of social problems, including the increase in violence and crime.

From this perspective, Chagas (2014) states that areas of peripheralization are places that are conducive to the development of territories of crime, because they converge in environments with certain particularities, such as illegal occupation, fragile public security and institutions of public control, associated with scarce minimum public services. These factors compete for zones of tension to be installed and fixed. In this way, crime, especially violent crime, becomes a coercive instrument to establish and control the territory by groups that articulate their actions in the urban space.

It is within this context that the territorial dynamics not only of lethal crime, but also all sorts of crimes such as those against property and the person can be observed, acting as elements of transformation and reorganization of urban space. It is also necessary to weigh the significance of the other processes that together can lead to crime, such as environmental, socioeconomic, political, and cultural ones, among others, in order to get closer to the perception of the areas of occurrence (FELIX, 2002).

When reflecting on violent crime from the perspective of the territory, it is evident that a theoretical and methodological effort is required that must consider the contexts and processes in which this territory is established. In this way, it is important to note that territory is recognized as a category subsequent to space and developed from the notion of space.

Space and territory are distinct concepts, where "space is the 'original prison', territory is the prison that men construct for themselves (...). Territory relies on space, but it is not space. It is a production from space" (RAFFESTIN 1993: p.144). Territory is made as a result of an action performed by a syntagmatic actor - who performs a program - on any level, which appropriates a space, concretely or abstractly, "territorializes" space (RAFFESTIN, 1993).

Different approaches coexist in the construction of the concept of territory. However, in any sense, the territory is linked to relationships or practices of power, which in this focus are based on the dynamics of violent lethality. In this context, the multidimensionality of power (BECKER, 1983; RAFFESTIN, 1993) is constructed in the sense that different actors produce space, structuring and restructuring the territory through the practice of powers applied in territorial management. To interpret territorial power means to relate it to the capacity of actors to manage, to implement policies with strategic impact on the territory by both the State and the multiple actors of / in power, in the production and use of territory (BECKER, 1983).

It is considered that the different social actors, especially local territorial agents, as representatives of social and economic power and the community in general, who are involved directly or indirectly or not yet related to the violent practices that can result in homicide, tend to "territorialize" themselves within their own intentions, transforming the territory into a stage centered on the conflict of interests and permeated by a web of relationships built by the different agents at the local level. 
In this sense, the power relationships established between agents and between them and the territory are complex and occur in multiple dimensions, in which power manifests itself and operates. Territory is conceived as the central stage of power relationships, essential in the construction of the territory's meaning (RAFFESTIN, 1993; SOUZA, 1995; SACK, 2013; HAESBAERT, 2004, 2014).

For Haesbaert (2004), the process of domination and / or appropriation and the issues of the territory must be worked in the multiplicity of their manifestations, taking into account the plurality of powers incorporated in them through the multiple agents involved. Thus, one must first distinguish territories according to the subjects that construct them, be they individuals, social groups, the State, companies or institutions. In this way, the territory is a product of the appropriation of a given segment of space by a particular social group, establishing itself in the territory from political relationships of control or affective relationships of identity and belonging.

According to Foucault (2015), power is not necessarily located in an institution, nor is it presented as something that is yielded by legal or political contracts. Power happens as a relationship of forces and, as a relationship, is everywhere. All are involved in power relationships and cannot be considered independent of them or outside them.

In this sense, Arendt (2011, p. 58) makes the distinction between power and violence in politics, stating that "the extreme form of power is All against One; an extreme form of violence is One against All. And the latter is never possible without instruments". The author emphasizes that violence is not a synonym of power. "(...) Power is in fact the essence of all government, not violence.

Violence is by nature instrumental; with all means, it always depends on the orientation and justification for the end it seeks." (ARENDT, 2011, p. 68). Thus "violent action is governed by the means-end category, whose main characteristic when applied to human affairs, was always that the end is in danger of being supplanted by the means it justifies and that are necessary to achieve it".

Thus, "nothing is more common than the combination of violence and power, nothing less frequent than to find them in their pure and therefore extreme form" (ARENDT, 2011, p. 63). So, although distinct, power and violence are usually found together. Thus "power does not need justification, being inherent in the very existence of political communities; what it really needs is legitimacy (...). Violence may be justifiable, but it will never be legitimate" (ARENDT, 2011, p. 69).

When the object of this study is analyzed, it is necessary to understand the materialized form that violence presents itself in the urban space. Thus, "violence corresponds to the use of physical force against the person, whose life, health and physical integrity or individual freedom are in danger from the action of others" (SAPORI, SOARES, 2014, p. 37). However, it is important to understand lethal violence, here understood as "the intentional use of physical force, directed against the aggressor or against others, and which results in injury or death" (BARATA; RIBEIRO, 2000 p. 118) making homicide a violation of the most fundamental right of the human being, the right to life.

The peripheral areas, where there the effective presence of the State is fragile, from its multiple regulatory institutions and emitters of state power, are where the proliferation of violence occurs most clearly, since the diversity of territorial agents fighting for control of the territory allows areas of tension to emerge, which often permits the emergence of lethal violence, justified by the need to achieve the inherent milieu in that area of territorial dispute.

\section{ANALYSIS OF INTERVIEWS}

The strategy of evaluating the local territorial agents' responses was based around the following questions summarized from the initial interview script:

i) Where and why are the deaths concentrated in the neighborhoods investigated?

ii) What are the profiles of the subjects involved in these violent practices?

iii) What criminal dynamics occurring in these neighborhoods result in death?

iv) What can be done in terms of public policies? 


\section{FEAR AND INSECURITY: \\ THE TERRITORIALITY OF VIOLENT CRIMES}

When analyzing the interviews, it was found that fear and the feeling of insecurity were factors present in the residents' daily lives. Several authors, such as Tuan (2005), Souza (2008) and Caldeira (2010) discuss how violence and insecurity have reached a critical level, capable of decisively influencing the populations' daily life and the patterns of circulation in space. Both fear and violence are elements that redefine people's way of life, presenting themselves "as conditioning factors of social relationships and the modeling of space in cities" (SOUZA, 2008: p. 13).

I don't feel safe walking around during the day or night, it's very dangerous people are robbing and killing for free (...) in fact, three months ago they killed two in the neighborhood in the daytime, about three o'clock (Resident 1, Congós neighborhood). |

We don't have any more freedom, that's how it is, we don't feel safe, we feel like we are in private prison, we're dying, we don't have any more freedom, because the Congós is a big neighborhood (...), in summer there is access to various bridges, they commit a crime and run (Representative of the Community Safety Council, Congós neighborhood).

I know of a case now, more recent, two men, they were murdered, I think the carnival had already started (...) two deaths. (Resident, Muca neighborhood).

Some of the responses highlight, among other aspects, the discomfort generated by fear and the feeling of insecurity in the subjects, especially when circulating in the streets and public spaces of the neighborhoods where they reside, not only at night time, but at all times of day and night. They also point to the injury or limitation of rights, especially with regard to freedom, which seems to feed a sense of loss of this guarantee, in addition to indicating a notion of enclosure associated with the idea of arrest, factors already recorded by Caldeira (2010).

Another issue expressed was the low value attributed to life, indicating that the residents' existence is immersed in a daily life of trivialization of death and violent practices that do not seem to have limits, in view of the collapse of systems of social values and coercive parameters that either are not respected or have lost their meaning (ADORNO, 1988), as well as pointing to temporal traces of increasing records of crimes close to occasions and holidays.

As to the territory of the neighborhoods where the deaths are concentrated, it has been reported that one of the causes of fear of moving around at night is the structure of spaces integrated by "bridge areas", which facilitate the criminals' escape. Tuan (2005) points out that people residing in a particular space have specific experiences of it based on the knowledge and construction they make of the surrounding reality, since they are integrated with the place in which they live, which is therefore their center of significance.

There is a significant less widespread or implicit aspect of the meaning relating to the feelings engendered by the territory, "(...) the fear of those who are excluded, satisfaction for those who enjoy it or identify with it" (HAESBAERT, 2004, p. 44). Therefore, territory is considered in its double connotation, material and symbolic, "because etymologically it appears as close to terra-territorium as to terreo-territor (terror, terrifying) "(HAESBAERT, 2014, p. 57), that is, it is related to juridical-political domination and to the inspiration of terror and fear. Territory is simultaneously objective, functional and symbolic, a guide to identity and appropriation, loaded with the marks of lived experience (LEFEBVRE, 2000; HAESBAERT, 2014). 


\section{THE PROFILE AND RELATIONSHIP OF THE AUTHOR AND VICTIM OF VIOLENT CRIMES}

With regard to the profile of the victims, many interviewees report that they are young, low-income men who are directly involved in different types of crime, such as robberies, theft, drug dealing and consumption, similarly to the findings of Beato Filho (2012).

Here in the neighborhood, the victims are mostly men and adolescents, usually thirteen to seventeen Resident, Jardim Felicidade).

To tell the truth, they are boys, sixteen, seventeen, living unregulated lives, without monitoring. It's their lifestyle, it is all this bad situation, drunkenness, delinquency, drugs and even violence (Businessperson Cidade Nova neighborhood).

It is observed that homicides in Brazil represent a worrying social issue, as well as a public health issue (MELO, CANO, 2012), and a serious violation of human rights (WAISELFISZ, 2014).

It is important to emphasize a discourse that clashes with this male profile of the victims, which points out that women are vulnerable to this type of crime, which may indicate a possible relationship, among other reasons, with violence against women, and even to the practice of femicide (WAISELFISZ, 2015), as well as the increasing participation of women in urban crime (PASINATO, 2011).

It's usually women and adults because of drugs. Children, we rarely see, this is the case in our neighborhood (Resident 2, Congós neighborhood).

Concerning the question of how the relationships between authors and victims are processed, some interviewees report that they know or have heard of homicide cases in their neighborhoods. However, for the most part they do not know if there was any affinity between author and victim. The main factors mentioned as augmenting the commission of this type of crime are the interpersonal problems and conflicts arising from the use and trafficking of drugs (PAIXÃO, 1994; SOARES, 2008).

Look, you know, I lost a neighbor, my childhood friend, he was a good person. Except that the drug trade got him into drugs (...) he was a victim of this, he was murdered here in the neighborhood (Resident, Muca neighborhood).

Last month here in Benedito do Carmo, on the corner of Twentieth avenue, very close to the police base, two bad guys arrived by bicycle and took the lives of two family men who had nothing to do with the problem. It was a drug fight (Priest, Congós neighborhood).

\section{THE DYNAMICS OF LETHAL VIOLENCE: MULTI-CAUSALITY}

The interviewees point to the issues of population growth, social vulnerability due to the absence of the State and especially the lack of investment in education, health and safety, the lack of employment and occupational opportunities, family disruption, drug trafficking and the culture of the trivialization of life and death, as broader and more general causes of the increase of violence in the neighborhoods. 
With the growth of the population and the rest, and the lack of structure, it's not just the school, it's families on a low income, who are unemployed, poor health care, all this impacts on the family structure, there are lots of things, problems, all of this (...) causes violence and drug dealing, like the lack of opportunities. (Resident, Cidade Nova neighborhood).

I'll tell you here in Marabaixo it is very big, there are a lot of young people doing nothing, unoccupied, it's sad, we're forgotten here in the neighborhood (...) there's a lot of danger with this drug thing for children and adolescents (Resident, Marabaixo I neighborhood)

Look, there are people here every day asking for a job, because there aren't any today, what is the young person going to do, we have nothing, we do not have a social project (Businessperson, Congós neighborhood).

Regarding the lack of education and work opportunities, Cerqueira and Moura (2014) investigated the causal effect of work and educational opportunities on the homicide rate in Brazilian municipalities, and emphasize that greater opportunities both in education and in the job market are crucial to lessen homicide rates in the country's cities.

Most of the cases here in the Congós neighborhood are motivated by settling scores, because there are a lot of dealers in the neighborhood, a lot of drug dealers, lots of drugs. (...) and we are always worried about our children, our grandchildren, the children who live here in the neighborhood because there is a very large number of children buying and selling drugs (Representative of the Community Safety Council, Congós neighborhood).

I think it's the power of drugs, the power of the faction, I've seen this... there they fight to see who rules the most (...) then they kill each other (Teacher, Congós neighborhood).

It is interesting to note that some considerations have been made regarding territorial disputes by rival drug trafficking groups, which, induced by the demonstration of power and expansion of territorial dominance, materialize their disagreements through killings. In this case, it demonstrates that homicides are often drug-related and score-settling related to drug trafficking.

From the universe of neighborhoods investigated, we can see that the Congós neighborhood distinguishes itself more explicitly as a "space defined and delimited by and from relationships of power" (SOUZA, 1995, p. 78), expressing the contradictions and conflicts involving the use of the territory. Thus, when assessing the perspective of violence, in particular when lethal, in its articulation with the territory, one perceives that the former is a cut from the second and can be identified through the context and its peculiarities (RAFFESTIN, 1993).

Associated with this universe of analysis, there is the process of peripheralization that produces new territorialities, among them the territoriality of violence and / or criminality. Raffestin (1993) guarantees that there is no power vacuum, because where the state is not present, agents tend to become territorial, such as community leaders, churches, small economic agents and even criminal groups. Thus, the emergence of a subnormal cluster feeds a new point in the space to be disputed and conquered by these agents (Chagas, 2014).

Therefore, it is necessary to point out how strategic the action of certain groups in a territory can be by "affecting, influencing, or controlling people, phenomena and relationships, by delimiting and ensuring their control over a certain geographic area" (SACK, 2013, p. 76). In this scenario, once again, Raffestin (1993) clarifies that establishing territory derives from a production of space that involves multiple relationships; an arrangement of relationships called the "field of power," or " territory of fighting," resulting from the spatial clash of powers that permanently contend for positions that enable not the definitive conquest, but the provisional or unstable exercise of territorial power.

In order to strengthen reflection on the concept of power in the intra-urban territorial sphere, Foucault (2015) is used, for whom the vision of power is not located in an institution, nor is it 
something ceded by legal or political contracts. Power happens as a relationship of forces and as such is everywhere. All are involved in power relationships and cannot be considered independent of them or outside them.

This perspective establishes a broader dimension of consideration, which includes the microphysics of a much more capillarized power, the power of subjects acting on other subjects (Foucault, 2015), in an unequal and continuous movement of domination and resistance that never is external to itself; "dominated" groups are always rebuilding their territorialities (HAESBAERT, 2014).

Aligned with this thinking, a large part of the power relationships currently involves different subjects and spaces of territorialization in a very sophisticated game with the state structure, mainly through illegal circuits, as is the case of drug trafficking, a phenomenon observed by local territorial agents (HAESBAERT, 2014).

From this perspective, it is verified that power does not exist in itself, what exists are practices of power in a given social space, that is, relationships of power, which refer here to the conjunction of concepts of space, territory and power, in the specific context of the study of violent lethality in Macapá.

\section{PUBLIC POLICIES: ROLE OF THE POLICE AND CRIMINAL JUSTICE}

With regard to public policies for reducing lethality in neighborhoods, the subjects generally assessed that they were not aware of any measures taken to reduce deaths, especially in relation to preventive strategies, especially by the federal government, and that the municipal level is not directly responsible for this action. There are tendencies in the sense that there is no incentive for cooperation between the three levels of government, which can lead to the inadequate allocation of financial resources for the execution of actions and policies to combat violence and crime.

The federal government is not doing anything for us (...) they do not invest in education or security, which are basic, so it is difficult to expect improvements at the federal level, you know? (Resident 2, Congós neighborhood).

With the goal of bringing improvements, respondents pointed out the need for investment in social areas by the federal, state and municipal governments together and with the participation of the community.

I think Federal Government help so that there was an institution to which we could take our young people. People doing those social and educational measures and we could take these young people off the street, from the world of drugs, drink, robbery, homicide, everything. I think if we had a Federal Government institution or a partnership here and we had an institution, I think it would reduce this a lot (Representative of the Community Safety Council, Barrio Muca).

A distinct response from the subjects is the possibility of decentralizing budgets and investing in the areas of safety, education and health, also pointing towards providing more leisure for children, as well as encouraging young people and residents from the community to use empty spaces in order to improve the population's quality of life.

With the tax we pay, we should decentralize more of that money. You should get it, get it like I said about school, the bottom line of all this, you have to start there in the classroom, so you have a good, good person, a character has to start there from below, we should give more support to the teachers, have better working conditions, have a living wage, no need to have a police car in front of the school, (...) 
the federal government should give more support to NGOs (...) they should do this, give conditions to anyone who wants to work. I doubt if there is good strong social work, leisure for these children, plant vegetable gardens, there is lots of land, teach the child to plant, for their own food (Teacher, Congós neighborhood).

In general, the discourse of the territorial agents indicates a broader interpretation of the public security policies, such as public social policies, which are no longer effectively implemented in the traditional language of rights and are now justified as crime control resources, subsidiaries of direct police repression (SILVA, 2014).

When analyzing the responses on the role of the institutions of the security and criminal justice system, most interviewees point out that there is an effort on the part of the civil police to investigate cases of violent crime. However, they emphasize the issue of "invisibility" and the economic conditions of those involved, which reveals a situation of penalization of the popular strata resulting from an intense process of social-territorial segregation, accompanied by a "silencing" that distances them from participating in the collective social order, as Silva (2014) points out.

I will be very sincere; we see that they get the culprit when it interests them. That's very sincere, it's difficult, because if you are not anybody, let it go, forget it, understand?! That is what I think (Community leader, Congós neighborhood).

On the one hand yes, but what happens, they go for it, but if they can't, the guy has died, but he is from a family down there, they can't get a good lawyer and so (...) what's going to happen (...) that case is going to be filed, just like that, put into the drawer of oblivion (Resident, Marabaixo I neighborhood).

Often yes, but often they go from here to other states, and sometimes die even before being investigated (Representative of the Community Safety Council, Congós neighborhood).

Another factor is the lack of preventive actions by public security agencies. Some report that the military police works in partnership with the community, however, the institution does not have all the resources to perform a better job of prevention, because it especially lacks structure, equipment and personnel.

The police are our partners, they have helped a lot, we see them going past all the time, they do the normal route, but also they can't do very much, sometimes the car is no good, these guys should be better supported, very well followed up, better vehicles and weapons, because they don't only arrest, they do the prevention, they do what they have to do, what it is up to them today, what they can do, I do not have anything to say against the military police do, they do a good job as far as possible (Businessperson, Cidade Nova neighborhood).

Currently there is a police project there (...) military police here near the roundabout they are with some young people there (...) it's a police project, right? They are good for our community, but we need a lot more (Resident, Muca neighborhood).

We have a very good partnership with the military police, at the moment they are very present, in schools, now the neighborhood has cars doing patrols. But police itself has no structure, cars are broken, sometimes they don't have fuel, it is over three years since the military police has had entrance examinations. Back when there were more cops walking around here, there was less danger. It's very complicated, drug use happens inside the school, there's no way the police can handle it, it's a very large neighborhood (Representative of the Community Safety Council, Congós neighborhood).

In this context, it is interesting to highlight a significant receptivity of the community regarding the attention given by the police, especially the military police, through social projects and parti- 
cipation in the Community Public Safety Councils (CONSEG), ${ }^{6}$ which shows that the connection between the local level of organization and the interaction with external institutions is a differential element. The existing security councils appear as efforts that consolidate the interaction between public security agencies and the community, especially in the Congós neighborhood.

In relation to the effectiveness of the role of the justice system in reducing the violent crime index, it can be verified that there is dissatisfaction on the part of the population, the interviews show the idea that "the police arrest and the judiciary sets loose", which passes by direct and indirect criticism of criminal legislation and juvenile justice measures, revealing the feeling of impunity (CHAO et al., 2007) present in the imagination of territorial agents.

But if they get the guys it would lower these rates, for example they both killed and not a month went by and the guys were already free (...) and they know the police do nothing and don't follow up and when the police catch you, if you pay a lawyer and then you're free to do the same things (Resident 2, Congós neighborhood).

\section{FINAL CONSIDERATIONS}

The purpose of this research was to address violence and lethal violent crime in the urban context of the city of Macapá, with emphasis on the neighborhoods that concentrate the highest rates of lethal violent crimes in the capital, based on the qualitative analysis of interviews with local territorial agents in the communities investigated. We sought to understand the relationship between the dynamics of lethal violence represented by homicide, robbery-homicide and death resulting from police confrontation and the behavior of local territorial agents.

The intended interpretation was delineated around the idea of adding the analysis of space and territory to the dynamics of social relations and power. The formation of the territory of violence in the capital of Amapá was reflected, in part, as a product of the tension of the relationships of the different local territorial agents, but was also characterized as a result of the low socioeconomic and infrastructure indicators of the areas analyzed, especially the Congós, Muca and Novo Buritizal neighborhoods, located in the southern part of the municipality, which are flooded parts of the territory, popularly known as ressacas, which have historically been used by the local population as a housing option, as well as for the development of economic, social, cultural and leisure activities.

The results point in the direction that these deteriorated spaces have a close connection with the violence in the territory of the municipality, besides being configured as areas of great socioeconomic vulnerability, particularly marked by educational and family deficits, by the culture of trivialization of violence, materialized in interpersonal disagreements, the scant presence of police officers and the conflicts related to the abusive use of alcohol and drugs, in a generalized context of the deficiency of the state apparatus.

A recent diagnostic study on homicides in Macapá has pointed to indicators of interpersonal violence, gang and drug conflicts, and lack of the presence of state agencies as positive and serious determinants. It also shows that indicators of domestic violence and conflicts between the police and the population stand out negatively, in an intermediate form in the capital (ENGEL et al., 2015).

Some points from the interviews are worth mentioning, such as the sense of fear and insecurity experienced by the community in these spaces, as well as the population's sense of invisibility regarding the lack of assistance on the part of the various spheres of government, in addition to the issue of the effective punishment of offenders.

(6) They are entities in support of the public security organs of Amapá, in the relationships with the community for the joint solution of social problems based on the philosophy of community security, linked by adherence to the strategic guidelines emanating from the National Secretariat of Public Security - SENASP / MJ (AMAPÁ, 2012). 
Following the logic of crime in other Brazilian capitals, the authors and victims of lethal crime are predominantly male adolescents and youths, due to conflicts arising from non-payment of debts related to the drug trade; this issue was very relevant and frequent in the reports.

Many of the power relationships observed currently involve different subjects and spaces of territorialization in a trajectory that follows the perspective of individual conflict and / or groups in a "game" with the state structure, mainly through the traffic of narcotics, a fact recurrently observed by local territorial agents in Macapá.

Finally, it is important to emphasize that the conflict between criminals is not the only dimension where power relationships are established in the territories of the neighborhoods investigated, many residents are very active, especially in the organization of community and religious leaderships and the CONSEGs, which continually address issues to improve the community's quality of life. It is in this scenario, in which the state presents itself in an inchoate way, that the territorial groups and agents gather, building up their "territorialities" from the use of lethal violence.

\section{BIBLIOGRAPHIC REFERENCE}

ADORNO, S. Os aprendizes do poder. Rio de Janeira: Paz e Terra, 1988.

ARENDT, H. Sobre a violência. Rio de Janeiro, 2011

BAILEY, T. C., GATRELL, A. C. Interactive spatial data analysis. Essex: Longman Scientific and Technical, 1995.

BARATA, R. B.; RIBEIRO, M. C. S. de A. Relação entre homicídios e indicadores econômicos em São Paulo, Brasil, 1996. Rev. Panam Salud Publica, Washington, v. 7, n. 2, p. 118-124, 2000.

BARDIN, L. Análise de Conteúdo. São Paulo: Edições 70, 2011.

BEATO FILHO, C. C. Crime e cidades. Belo Horizonte: Editora da UFMG, 2012.

BECKER, B. K. O uso político do território. In: BECKER, B. K.; COSTA, R. H; SILVEIRA, C. B. (Orgs). Abordagens políticas da espacialidade. Rio de Janeiro: UFRJ, p. 1-8, 1983.

BRASIL. Ministério da Justiça. Manual de preenchimento: formulário de coleta mensal de ocorrências criminais e atividades de polícia. Brasília: SENASP, 2006.

BRASIL. Ministério da Justiça. Projeto Segurança Cidadã: Pensando a Segurança Pública - Edição Especial Homicídios. Brasília: SENASP, 2016a.

BRASIL. Ministério da Justiça. Os números da Justiça Criminal no Brasil. Informativo Rede Justiça Criminal. n. 8, jan, 2016b.

CALDEIRA, T. P. R. Cidade de Muros. Crime, segregação e cidadania em São Paulo. São Paulo: Ed. 34/Edusp, 2010.

CÂMARA, G.; MONTEIRO, A. M.; DRUCK, S.; CARVALHO, M. S. Análise espacial e geoprocessamento. In: DRUCK, S.; CARVALHO, M. S.; CÂMARA, G.; MONTEIRO, A. V. M. (Orgs.). Análise espacial de dados geográficos. Brasília: Embrapa, 2004.

CARDOSO, M. A.; MOTA, P. D. M.; SILVA, L. C. da; MONTEIRO, S. C.; FERREIRA, J. F. C. O Despejo de Resíduos Sólidos nas ocupações irregulares no Canal do Jandiá (Macapá-AP). Revista Nacional de Gerenciamento de Cidades, v. 03, n. 19, p. 149-161, 2015.

CERQUEIRA, D.; LOBÃO, W.; CARVALHO, A. O jogo dos sete mitos e a miséria da segurança pública no Brasil. In: CRUZ, M.; BATITUCCI, E. (Orgs). Homicídios no Brasil. Rio de Janeiro: FGV, p. 141-176, 2007. CERQUEIRA, D.; MOURA, R. L. de. Oportunidades para o jovem no mercado de trabalho e homicídios no Brasil. In: CORSEUIL, C. H.; BOTELHO, R. U. (Orgs.). Desafios à trajetória profissional dos jovens brasileiros. Brasília: Ipea, p. 267-290, 2014.

CHAGAS, C. A. N. Geografia, Segurança Pública e a Cartografia dos Homicídios na Região Metropolitana de Belém. Boletim Amazônico de Geografia. n. 1. Jan./jun. p. 186-204, 2014.

ENGEL, C. L. (Org.); PARESCHI, A. C. C.; DANTAS, A. G. L.; LIMA, D.P.; ROMAO, D. M. M.; SAN- 
TOS, H. F.; BARBOSA, J. F.; NUNES, J. L.; LOIOLA, P. H. R.; SOUSA, R. R.; FABRI, S.; SOARES, V. L.; RODRIGUES, Y. S. Diagnóstico dos homicídios no Brasil. Brasília: Ministério da Justiça, Secretaria Nacional de Segurança Pública, 2015.

FELIX, S. A. Geografia do crime: interdisciplinaridade e relevâncias. Marília: UNESP, 2002.

FOUCAULT, M. Microfísica do poder. 2. ed. Rio de Janeiro: Paz e Terra, 2015.

GEAC-SEJUSP/AP. Gerência de Estatística e Análise Criminal da Secretaria de Estado da Justiça e Segurança Pública do Amapá. Sistema de Banco de Dados. Macapá, 2016.

HAESBAERT, R. O mito da desterritorialização. Rio de Janeiro, Bertrand Brasil, 2004.

HAESBAERT, R. Território e Multiterritorialidade: um debate. GEOgraphia, ano IX, n.17, p. 19-46, 2007.

HAESBAERT, R. Viver no limite. Rio de Janeiro: Bertrand Brasil, 2014.

IBGE. Instituto Brasileiro de Geografia e Estatística. Censo Demográfico 2010. 2010a. Disponível em: http://www.censo2010.ibge.gov.br/sinopse/index.php?dados=29\&uf=16. Acesso em: 31 jan. 2017.

IBGE. Instituto Brasileiro de Geografia e Estatística. Estimativas da população residente no Brasil e Unidades da Federação. 2016. Disponível em: http://www.ibge.gov.br/home/estatistica/populacao/estimativa2016/estimativa_dou.shtm. Acesso em: 13 fev. 2017.

LEFEBVRE, H. A produção do espaço. 4. ed. Paris: Anthropos, 2000.

LEFEBVRE, H. O direito à cidade. São Paulo: Centauro, 2006.

PALHETA, A. C., SANTOS, T. B.; SERDOURA, F. Segregação ou Integração dos Espaços Públicos Urbanos: uma análise da Zona Norte de Macapá - AP. $7^{\circ}$ Congresso Luso Brasileiro para o Planejamento Urbano, Regional, Integrado e Sustentável - Contrastes, Contradições e Complexidades, Maceió-AL, 2016.

PEREIRA, A. C. B.; SOUSA, J. C.; SILVA, R. T. Desigualdade social, áreas de ressaca e locais perigosos em Macapá/AP. 2015. Disponível em: http://eventos.livera.com.br/traba1ho/98-1019797_24_06_2015_13-52-09_3353.PDF. Acesso em: 18 fev. 2017.

PORTILHO, I. S. Áreas de ressaca e a dinâmica urbana em Macapá/AP. VI Seminário Latino-Americano de Geografia Física e II Seminário Ibero-Americano de Geografia Física. Riscos naturais e a sustentabilidade dos territórios. Coimbra: Universidade de Coimbra, 2010. Disponível em: http://www.uc.pt/ fluc/cegot/VISLAGF/actas/tema4/ivone. Acesso em: 15 jun. 2016.

PORTO, J. L. R.; CHELALA, C. A.; ANDRADE, E. B. O pensamento ambiental e as modalidades de unidades de conservação no Amapá. OLAM (Rio Claro), v. 8, p. 80-103, 2008.

RAFFESTIN, C. Por uma geografia do poder. São Paulo: Ática, 1993.

ROLNIK, R. Exclusão territorial e violência. São Paulo em perspectiva. vol. 13, n.4, p. 100-111, 1999.

SACK, R.D. O significado de territorialidade. In: DIAS, L.C; FERRARI, M. (Orgs.). Territorialidades Humanas e Redes Sociais. 2 ed. Florianópolis: Insular, 2013.

SAPORI, L. F.; SOARES, G. A. D. Por que cresce a violência no Brasil? Belo Horizonte: Autêntica Editora: Editora PUC Minas, 2014.

SILVA, L. A. M. Violência e Ordem Social. In: LIMA, R. S. de; RATTON, J. L.; AZEVEDO, R. G. de (Orgs.). Crime, Polícia e Justiça no Brasil. São Paulo: Contexto, p. 26-34, 2014.

SOUZA, M. L. de. O território. Sobre espaço e poder, autonomia e desenvolvimento. In: CASTRO, I.; GOMES, P. C.; CORREA, R. L. (Orgs.). Geografia. Rio de Janeiro: Bertrand Brasil, p. 77-116, 1995.

SOUZA, M. L. de. Fobópole. Rio de Janeiro: Bertrand Brasil, 2008.

TAKIYAMA, L. R.; SILVA, A. Q.; COSTA, W. J. P.; NASCIMENTO, H. S. Qualidade das Águas das Ressacas das Bacias do Igarapé da Fortaleza e do Rio Curiaú. In: TAKIYAMA, L. R.; SILVA, A. Q. (Orgs.). Diagnóstico das Ressacas do Estado do Amapá. Macapá-AP: CPAQ/IEPA e DGEO/SEMA, p. 81-104, 2003.

TOSTES, J. A.; LUZ, R. S. Planejamento urbano na cidade de Macapá: análise do projeto habitacional Macapaba. III Encontro da Associação Nacional de Pesquisa e Pós-graduação em Arquitetura e Urbanismo, arquitetura, cidade e projeto: uma construção coletiva. São Paulo, 2014.

WAISELFISZ, J. J. Mapa da violência 2014. São Paulo: Instituto Sangari, 2014.

WAISELFISZ, J. J. Mapa da Violência 2015. Distrito Federal: FLACSO, 2015. 